\title{
Some Major Causes of Current Economic Crises and Leadership Strategies
}

\author{
Asım Şen, Beykent University
}

\begin{abstract}
This paper argues that economic inequality is one of the major causes of the current economic crises and provides some appropriate leadership strategies for solving them. Inequality is defined as unequal opportunities for economical activities among the people of a nation and among the nations of the world. The major cause of most current economic crises is the income and wealth inequality which are generated mainly by the economic growth. Leaders in the past and currently could not utilize appropriate strategies to solve the inequality problems and consequently the economic crisis grew and reached the current levels.

In order to solve the current economic crises it is necessary to eliminate the economic inequality problems and establish fair and sustainable economic growth. The leadership strategies play crucial role for this process. These strategies included in this paper are establishing the local and global shared vision for all; balancing the income and wealth distribution; providing the equal opportunities for education and employment; sharing the production and consumption; and maintaining the fair and sustainable globalization and economic growth.
\end{abstract}

JEL Codes: O4, E2.

\section{Introduction}

The current local and global economic crises are often expressed with some economic activities such as bank failures, personal and corporate bankruptcies, rising unemployment and lowering income and wealth, declining production capacity, difficulties of paying back some of the credits, rising debts for some people, organizations and nations. This study considers also hunger, poverty, and per capita income, lack of health care and education, life expectance, infant mortality, environmental destructions, depletion of the world's resources part of the economic crises. People in different organizations and nations have been affected by some or more of these economic crises throughout the world.

The economic crises can not be explained by the crises of only some corporations, banks and the people affected in developed and developing nations alone. But, all the poor people in developed, developing, and underdeveloped nations should also be included in the definition of the economic crises. More than 1.1 billion poor people in East Asia, Latin America, South Asia, Sub-Saharan Africa, Middle East, and other regions of the world live in extreme poverty (poverty defined as $\$ 2$ a day, moderate poverty about $\$ 1.5$ a day, and extreme poverty $\$ 1$ or less than $\$ 1$ a day). Their economic crises of hunger and poverty which generate misery and anxiety for their life have not been included in the definition of the recent economic crisis. In fact, their economic crises have been with humanity for a long time not just for recently. It is therefore, more accrued and fair to include economic crises of many people of the world into the definition of economic crises.

The economic crises in the past and more recently were developed, mainly, during the economic growth. The economic growth is the main source of the income and wealth of a society which has been rising with the increasing production. In capitalist economies, declining in production reduces investment, employment, personnel incomes, savings, consumptions, and increases the personal debt of the consumers. Without employment, many individuals can not pay their debts and many banks can not collect their loans. Consequently, the total demand declines which stagnates investment, production and causes the economic crises in many organizations and nations. 
Recently, the presidents of many nations have been utilizing some strategies to find a solution for the current economic crises in developed and developing nations. However, these strategies are mostly attempting to generate short term employment by providing small amount of capital for some investors, householders, and bailout some of the troubled banks and corporations. These strategies may generate some limited employment and small demand for the short term, but will not solve the economic crises in the long term. In fact, many experts are predicting that, in spite of these strategies, the economic crises will have a "second dip". In order to find a viable solution for the economic crises, it is necessary to understand the root causes of the economic crises, and then design appropriate strategies to solve them.

This paper argues that unfair and unsustainable economic growth has been the main source of the economic crises. However, the inappropriate leadership strategies in the past and currently played a major role in this process. It is therefore necessary to change the contemporary leadership strategies to eliminate the current economic crises.

The main objective of this paper is to present some evidences that economic inequality causes the current economic crises and establish some appropriate leadership strategies that might be useful for solving them.

\section{The Root Causes of Economic Crises}

The economic growth is the major objective of the capitalist economy and the main source of human prosperity. This process can be explained with some of the major economic activities that are essential for producing goods and services to satisfy the human needs and wants. These major economic activities that generate economic growth include the investment, employment, income, consumption and saving. The rate of economic growth, partly, depends on the relationship of these activities and the size of the raw materials that they use and the demand for the goods and services that they produce.

In capitalist economies, the investors utilize the limited resources to satisfy the existent demand for making profit. In an organization, in a chain reaction, the investment generates employment; employment generates income for labors and investors. Some of these incomes are spent for the consumption and some of them are saved for further investment. When there is enough demand, investors use the opportunity and the raw materials to produce goods and services to satisfy the existent demand in a free market. As a result of continuation of this process, the economy grows and the people of organizations and nations get prosperous. Therefore the investors, employees, consumers, governments, and most other people like to have economic growth.

However, the recent economic crises have shown that the market is not that free; it is partly controlled and directed by the leadership strategies. These strategies are mostly based on maximizing the personal interests of the owners and leaders of the business organizations. The interest of the employees, consumers and most people are often neglected. These kinds of unfair and biased strategies have been causing income and wealth inequalities within and between nations. These inequalities provide the economic power for the leaders and the owners and generate economic crises for the employees. The decisions of distributing the benefits of the organizations, determine the rate of salaries and the duration of employment. These decisions are made by the leaders who are elected or appointed by the owners. Therefore, they have been favoring the owners' objectives and securing their own employment.

Growing economies and rising world population have been generating another kind of inequality between finite world resources and rising demand for them by destroying the environment and depleting the finite resources. These kinds of inequalities are also causing some economic crises for everyone especially the poor people who are dependent on the environmental resources for their livelihood. 


\subsection{Some Data for Economic Growth, Inequalities and Economic Crises}

During the period of twentieth century and early part of the twenty-first century, economic growth of the world has been phenomenal. But, its growth rate and distributions of the benefits and costs, among people of organizations and nations, have been unequal and causing economic crises.

During the last six decades, the economic growth of global economy which is now more than five times the size it was in 1950, has not brought about equivalent progress of fulfilling basic human needs to adequate food, access to health care and education, and decent employment. In a world of nearly 6.7 billion people, 4 billion of them still live in poverty and 1.1 billion live in extreme poverty (Jackson, 2009; Collier, 2007).

The economic growth in terms of world income or world per capita income, and the world population have been growing exponentially since 1800 (Sachs, 2008). But, the growth rate and its benefits have been distributed unequally within and between nations. The group of 7 developed nations (G7) consisting of the United States, the United Kingdom, France, Italy, Germany, Canada, and Japan have managed to grow several times faster than the developing nations and live longer, healthier and more prosperous. During 1970s and 1980s the G7 was the world's dominant economic power through their relatively high economic growth (Marber, 2009).

During 1980s, 1990s, and 2000s some of the developing nations called the Emerging 7 (E7) consisting of China, Russia, India, Indonesia, Mexico, Brazil, and South Korea, and other G20 nations also obtained relatively high economic growth (Marber, 2009).

The G7 nations having combined 700 million people produced \$25 trillion worth of economic output in terms of purchasing power parity (PPP). The E7 nations having combined about 3 billion population, more than 4 times of the G7 nations, produced about $\$ 19$ trillion in 2009. It is estimated that these figures will be about $\$ 67$ trillion for G7 nations and $\$ 105$ trillion for E7 nations by 2050 (Marber, 2009).

According to United Nations Human Development Index (HDI) the lower and middle income nations' was about 20 to 32 percent of that high income nations' in 1960. These figures went up respectively 34 to 62 percent by 1993 and 65 to 85 percent by 2006 (Marber, 2009).

The growth rate of one sixth of the world population achieved high income; two thirds with a modest rates of economic growth; and one sixth of humanity stuck in extreme poverty with very low and most with negative rates of economic growth during the period of 1820 to 2001 (Sachs, 2005).

The richest 20 percent of the world population earn 74 percent of the global income and the 20 percent poorest earn only the 2 percent. The life expectancy is about 50 years, whereas 70 to 80 years in other countries, infant mortality is 14 years, whereas 4 years in other countries, health and social problems are relatively much higher, level of education and literacy is lower, homicides and crime rates are higher, in these countries with a low national income per capita; Human Development Report's Index is about 0.8-1.0, whereas 0.2-0.5 in other countries (Wilkinson and Pickett, 2009).

The inequality of wealth accumulation is also severe in the U.S. The top 1 percent of population owned 46 percent of total financial assets, the next 9 percent owned 36 percent and the rest 90 percent owned 18 percent. Top 10 percent of population owned 82 percent of total financial assets, 91 percent of total corporate and business assets and 75 percent of the total wealth in 1997. The rich person on average has 230 times more wealth than a large majority of Americans. About 5 percent of the population owned the 95 percent of the wealth and 95 percent of the population owned only 5 percent of the wealth (Brouver, 1998; Sachs, 2005).

If the distribution of income and wealth generated by the economic growth remains so unequal, the economic crises will grow and more people will be in poverty by the middle of this century when population expected to rise over 9 billion (Jackson, 2009). 


\subsection{Some Unfair Leadership Strategies and Economic Crises}

Leaders in the past and currently could not provide necessary strategies to eliminate the inequality problems and establish a fair and sustainable economic growth. The leaders of most corporations and governments want growing gross national product (GNP) through economic growth. The economic growth provides opportunities for leaders of many corporations to maximize their profits and strengthens the leaders of many governments' political positions through increasing gross national product.

But the leadership strategies for distributing the benefits of economic growth have not been fair. Their strategies have been favoring mostly the interests of the investors and the owners of the organizations. These kinds of strategies make the inequality of income and wealth between rich and poor even worse. They influence and play the major role for making the main decisions for employment, level of salaries, and sharing the outcomes of the organizations. Most of these decisions satisfy the interests of their affiliated groups (stockholders, investors, and politicians) and their own.

The leaders who are elected by the board of trustees (BOT) of the stockholders or appointed by the owners in many organizations have been favoring mainly the interests of the stockholders and the owners (Derber, 1998; Estes, 1996; Galbraith, 1998; Thurow, 1989; Reich, 2007). The leaders of the governments have also been supporting, mainly, the interests of the corporations who support them financially and politically. Thus the interests of the employees and the customers have been neglected (Batra, 1996; Blair, 1994). These kinds of leadership strategies increase the economic inequality and cause the economic crises.

Some of the real world practices support these arguments. The recent enormous economic growth has generated severe income and wealth inequalities for people within and between nations. The income of some major American companies' CEOs were 25 to 30 times more than the typical workers' wages during the 1950s and 1960s. This figure grew up to 40 times in 1980 and 100 times in 1990 and 350 times in 2007 (Wilkinson and Pickett, 2009). Average pay of CEO in the U.S. rose 57 percent between 1990 and 2000, while the average worker pay rose 37 percent in the same period. CEO salaries tripled in France, Italy, and Britain and doubled in Germany during 1984-1992.

Since 1976, inequality between real wage workers has soared in U.S. Workers' wage index fell 14 percent by 1995, while executives' jumped 150 percent (Batra, 1996). This ratio increased to 690 in U.S. in 2000. Salaries of CEO's of Fortune 500 went up from 35 to 157 times that of production workers (Blair, 1994; Rose, 1994 -1995).

The leaders and owners of many organizations and nations, who are the major agents of the causes of the current economic crises, can also play a major role for solving them. Some of the leadership strategies for this purpose are presented below.

\section{Some Leadership Strategies for Solving the Economic Crises}

There is a Turkish saying that "fish starts smelling from the head". Elimination of the sources and solving the recent economic crises should start first with the leaders of organizations and governments throughout the world. Currently, the leaders of many organizations and governments are utilizing some strategies to avoid world wide economic recession. These strategies may generate some limited employment and increase the total economic demand for the short term, but will not be effective for solving the economic crises in the long term.

In order to eliminate the sources of inequality and solve the current economic crisis for a short and long term, it is necessary to start democratizing and globalizing contemporary leadership practices. The leaders at every level of organizations and governments throughout the world should think and act fairly and ethically for local and global economic affairs to solve these crises.

The leaders of the organizations, unions and the governments should work together locally 
and globally to include the employees and the consumers in the major decisions of the organizations. This kind of industrial democratization will establish equality of income and wealth among people and maintain fair globalization and sustainable environment. The industrial democratization will also provide equal economic opportunities for everyone to participate in political activities. Without industrial democratization we can not have political democratization. The following sections provide some of the leadership strategies for this purpose and may help to solve the current economic crises.

\subsection{Strategy of Developing Local and Global Shared Vision}

In order to solve common local and global economic crisis we need to develop leadership strategies that are based on "we, the united" rather than "we and they, the divided". This is possible through establishing a leadership strategy with a shared vision for every organization, nation and the world.

The vision of most organizations has been the profit maximization based on the argument that the social responsibility of an organization is to make money for the shareholders and the owners (Friedman, 1970). Data indicate that the profits of most organizations have not been shared fairly by all the stakeholders. Most of the gains went to the owners, the stockholders and the leaders who make the major organizational decisions.

Local and global economic crisis are common to all nations. In order to solve the common and global problems, it is necessary to establish the shared vision and joint strategies and efforts. Historical and the contemporary global events indicate that even the most powerful nations can not solve the global problems alone. The global problems require globally joint efforts for a fair solution.

The shared vision of the organizations and nations should be to achieve the quality (prosperity) with equality (equal opportunity), and liberty (personal freedom and national independence) throughout the world.

In order to establish the shared vision the leaders and the citizens of each organization and nation have to work together for having quality with equality and liberty for everyone. This can be established through democratization of leadership practices through group decision making, sharing the benefits and costs of the economic growth, securing the employment in organizations and nations (Sen, 2003).

The process of building and implementing the shared vision has to be the major responsibility and duty of the leaders. They have to respect freedom, independence, and rights of all the stakeholders of organizations and nations. They should cooperate to solve common problems for local and global peace, prosperity and happiness. Organizational and global unity, understanding, respect and care for one another are necessary for solving the contemporary economic crisis at local and global levels. Shared vision will help to establish and strengthen the unity and cooperation among all the stakeholders locally and globally. A quality without equality generates economic, social, and political crises (Chasin, 1997).

\subsection{Strategy of Balancing Income and Wealth Distribution}

During the recent economic crises, the income of many corporate leaders and the profits of many corporations and banks are increasing despite the huge layoffs and the households' debts. It seems that the economic crises have been increasing the income and wealth of the high income groups and lowering the income and wealth of the low income groups. The leaders of organizations and governments have to adopt strategies and policies to balance the income and wealth between high and low income groups.

Leaders of the organizations should balance the high and low income by increasing the income of low income groups and lowering the income of the high income groups. There is of course no theory for determining the lower and upper level limits of the salaries. But, in order to eliminate the inequality and maintain the economic stability, the current ratio of average 
high incomes to low incomes should be reduced. In 1990s, this ratio was about 6 to 1 in USA, 3 to 1 in some Scandinavian nations including Sweden, Belgium and Netherlands (Marber, 2009). The inequality is the lowest in these nations. The ratio of 3 to 1 that they maintained should be a good measure to reduce the incomes of the high income groups and increase the incomes of the low income groups.

The progressive tax programs for high income, capital gains, land, and inheritance for luxury goods and services have to be used for eliminating the income and wealth inequality. These kinds of practices have been very effective for reducing the income and wealth inequality in many Scandinavian countries which have relatively very low inequality (Sachs, 2005; Wilkinson and Pickett, 2009; Jackson, 2009; Speth, 2008).

The corporate leaders should also adopt the programs such as profit sharing, gain sharing and employee stock ownership program (ESOP) to become an owner of the organization. Employee ownership plans saved many companies from bankruptcy and increased he productivity over time (Adams and Hansen, 1992; Blair, 1995).

Many organizations in Japan, Germany, and France, who are given relatively more voice in their employees, get better equality than the U.S. In these countries employees are considered long-term stakeholders of the companies and are permitted to participate in major management decisions. These kinds of participative decisions, sharing the organization's responsibility and the benefits will increase the employee loyalty, eliminate the inequality and increase the prosperity of all stakeholders.

\subsection{Strategy of Providing Equal Opportunities for Education and Employment}

Knowledge, skills and values are the main determinants of income and wealth generation and accumulation. The workers completed six years of education earn 50 percent more than the workers who do not attend school. The gap widens 120 percent for an employee with 12 years education and exceeds 200 percent for those with university diploma (Haussmann, 1998). These figures imply that income inequality arises from education distribution pattern for the employment. People who do not have good economic conditions to go to good schools for a good education mostly end up with low paying jobs and have low income. Thus the inequality in education generates inequality of income and wealth.

During the period of 1990-1995 average corporate layoffs were about 500, 000 in U.S.A. These figures were increased during the last decades and many corporations are planning to have larger layoffs because of the recent economic crises. Many corporations are forcing their employees to work longer hours even during the weekends. Leaders of every organization and government should try to provide equal opportunities for every citizen to eliminate the income inequality and increase the job security.

The yearly military spending of U.S. could provide university scholarship for 30 million students (Marber, 2009). The U.S. military easily cut back without jeopardizing its security. The military spending in many developed and developing nations are similar to or worse than the U.S.A. The leaders in the U.S. and in many other nations should cut down the defense spending and increase the financial helps for those who can not afford education.

The leaders of every public and private organization should also provide and maintain equal opportunities for employment. Hiring for short them purposes and firing when the profits are low is not productive and increase economic crises. The leadership practices should provide opportunities for sharing and securing the employment for a long term. This will increase the moral, loyalty and productivity of the employees. This in turn increases the returns and decrease the inequality and economic crises. Thus providing equal opportunities for education and securing employment are essential for eliminating the current economic crises.

The leaders should also provide opportunities for sharing and securing the jobs with a long term employment. Two third of the Japanese organizations are providing life time employment for their employees (Sen, 1982). Long term employment will increase the employees' moral, 
loyalty and productivity. This in turn increases the organizations' returns and decreases the inequality and economic crises.

\subsection{Strategy of Sharing and Maintaining the Sustainable Production and Consumption}

The inequality gap of production and consumption between developed and developing nations is very high. The developed nations including the U.S., Japan, Germany, France, Italy and the UK provided 71 percent and the 16 big twenty nations and other developing nations 21 percent of the total world's output in 1993. They also consumed the largest portion of the goods and services of the world (Knox and Agnew, 1998).

The richest 20 percent of the world's population consumes 86 percent of all the goods and services. The poorest 20 percent consume only 1.3 percent. Meanwhile more than 1.1 billion people leave on less than $\$ 1$ a day (Collier, 2007).

The production and consumption are increasing with an increasing population of the world while the world's resources are decreasing (Marber, 2009; Sachs, 2008). Increasing production and consumption and decreasing limited world's resources are causing economic instability and environmental problems.

In order to solve inequality and economic crisis, the leaders and the people throughout the world need a radical change in production and consumption activities. This process requires some attitude adjustment, pain, and sacrifice which will resolve the economic crises by slowing down the high level of production and consumption. We can not afford production and consumption that the environment can not provide sustainably.

In order to reduce the inequality gap and maintain fair and sustainable production and consumption, the developed nations should focus on new frontier technologies. They can support the new R\&D, innovations, new knowledge and skills required for these production technologies. Meanwhile developing nations should focus on developing the standardized technologies where they have comparative advantages of production. This process will increase their share of production and consumption for the goods and services that developed nations produce. They will mutually gain from this process through increasing employment and reducing economic crises locally and globally and generate win-win situation for both developed and developing nations.

The local and global leaders of both developed and developing nations should create an environment in which a sustainable production and consumption is possible. The agreements of global partnership for sustainable development are discussed in international meeting in Doha in 2001, in Mexico in 2002 and in other international meetings. These kinds of global agreements should be increased to establish the global cooperation for sustainable production and consumption.

The leaders should establish new organizations to provide credit for investment and education similar to Muhammad Yunus' microfinance revolution through Grameen Bank (Mohammed, 2007).

The leaders of organizations and nations should start giving up wasteful production and unfair consumption and adopt sustainable production and consumption. For this, it is necessary to decrease spending today and increase saving for tomorrow. Small changes in our lifestyle today may provide quality with equality and security for tomorrow.

\subsection{Establishing Fair Globalization and Sustainable Economic Growth}

Many industrial organizations and nations have been obtaining major benefits from the globalization. However, the major benefiters from the globalization have been the main developed nations including U.S.A., Germany and Japan (Isaak, 2005; Stiglitz and Charlton, 2005; Marber, 2009). The nations engaged in globalization increased their income and wealth considerably (Carney, 1995; Marber, 1998; Garten, 1997). Some of the newly developing 
countries (NICs) also increased their economic growth considerably through globalization. However, the distribution of the benefits among the nations is quite unequal.

Limited world resources can not supply this huge and continuously increasing global production sustainably. The environment has been giving warning signals that it can not supply continuously growing demand of the increasing world population (Marber, 2009: Jackson, 2009; Sachs, 2009). These problems will not solve themselves. The leaders should act collectively and abandon the individual self-serving interests and adopt fair globalization and sustainable economic growth. We can obtain prosperity without ever increasing economic growth by establishing sustainable system of energy, land, and resources that avert environmental hazards; stabilize the world population through voluntary reduction of fertility. We can end the extreme poverty in both poor and rich countries if we act collectively and fairly.

Theories of comparative advantages suggest that, nations could improve welfare of the population through globalization (Smith, 1776; Ricardo, 1981). The leaders of both developed and developing nations should act together to improve their comparative advantages through developing educational, technological, economical, and managerial conditions. The nations that developed these conditions jointly can improve their comparative advantages mutually and benefit from the globalization fairly. The leaders should act jointly to revise the biased rules and policies of the international agreements such as United Nations, World Bank, World Health Organization, World Trade Organization, and establish the shared vision with the new principles, rules and regulations to generate quality with equality for all and sustainability of the environment. The leaders of local and global public and private organizations need a genuine and urgent cooperation for establishing a fair globalization and sustainable economic growth to eliminate economic crises.

\section{Conclusion}

The inequality of income and wealth within and between nations and the inequality between supply and demand of the world resources have been generating economic crises through rising economic growth and world population. The past and current leadership strategies could not resolve the current economic crises. Contrarily some of these strategies helped the economic crises grow and reach to the present level. Many experts and scientists are warning us that if these crises will not be solved, growing inequalities and economic crises will be much worse and threaten human life in the near future (Marber, 2009; Sachs, 2008; Wilkinson and Pickett, 2009; Jackson, 2009).

For a long term solution, the leaders and the owners should abandon the self-serving biased profit maximizing visions of the organizations and nations and adopt the shared vision with the participative leadership strategies. The shared vision for individual, organization and nation should be maximizing the welfare with equality and liberty. The leaders, owners, and the employees of each organization and nation have to work together for establishing the shared vision to have quality with equality and liberty for everyone.

The leaders and the owners of the organizations have to adopt leadership strategies through maximizing everyone interests including all the stakeholders of organizations and consumers rather than maximizing the profit. Most of the organizations in Japan, Germany, and in Scandinavian nations have been utilizing leadership strategies to provide more benefits for the society rather than maximizing the profit. Most of the organizations in Japan use participative leadership strategies to generate quality with equality. The Management Consul in Germany makes the major organizational decisions which determine the major benefits including the salaries, employment and the French benefits jointly and fairly. The fifty percent of the members of the Consul are made by the employee representatives who are elected by the employees. These kinds of strategies can be used for reducing the inequality and economic crises. 
The leaders should also adopt policies to increase spending on the social services of the poor families for schooling, health and child care and community services. The evidence in some Scandinavian nations suggests that the high level spending in the social-welfare states rather than military is very effective in reducing the inequality and promoting prosperity. The socialwelfare states have achieved high level of income, low rate of poverty, and a more equal distribution of income than the practices of capitalist economies.

The existent science and technologies of the world are capable for solving the inequality and economic crises. All we need a common good will to do it. The leaders act collectively to revise the biased rules and agreements of the international institutions and establish new principles, fair policies, rules and regulations to generate quality for all with equality and freedom. The leaders need to establish a genuine and urgent cooperation for fair globalization and sustainable growth for eliminating the inequality and economic crises.

The government leaders should increase tax on the high income and wealth holders, and on inheritance, luxury goods and services, second houses and cars and other luxury consumption items to eliminate the income and wealth inequalities.

In spite of recent economic crises, many corporations and banks announced high profits. The government leaders should increase corporate taxes on high profit making corporations and banks, and reduce on small business owners who are having economic crises. They should provide credit and other financial helps for the new entrepreneurs to establish new business which will generate new employment. They should also adopt policies to reduce military spending and political campaigning.

The government and organization leaders can not solve the inequality and economic crises alone. The employees and the consumers should also participate solving these problems. The employees should increase their knowledge and skills to generate more value for their organization through increasing productivity. This will increase their job security and outcome of the organizations.

The employees should also organize and unionize to increase their participation in managerial decisions, and the bargaining powers for negotiating their employment, salaries and the French benefits.

The employees, managers, and leaders should also share the costs of their organizations. The wages of the workers, and salaries of the managers and the leaders should not be increased during the economic crises; they should be decreased for a short time if it is necessary to save their employment and the organizations continuity.

Finally, the consumers should try to cut down their consumptions for non essential and luxury goods, and services. They should also increase charities and help poor anyway they can for eliminating their economic crises. The finite resources can not supply the ever increasing consumption of the people. We should be fair for sharing and consuming the world resources now and in the future. There is an old saying that, the world may come to an end if one rich eats and the poor looks on.

\section{References}

- $\quad$ Adams, Frank T. and Gary B. Hansen, 1992. Putting Democracy to Work. San Berrett-Kohler Publisher, San Francisco.

- Batra, Ravi, 1996. The Great American Deception. John Wiley, New York.

- Blair, Margaret M. Winter, 1994. "CEO Pay: Why Such Contention Issue”. The Brookings Review. The Brookings Institution, Washington D.C., p. 23.

- Brouwer, Steve, 1998. Sharing the Pie. Henry Holt and Company, New York.

- Carney, Martin, et.al., 1993. The New Global Economy in the Information Age. Pennsylvania State University, Universiy Park. 
- Chasin, H. B, 1997. Inequality and Violence in the United States. Humanities Press, NJ.

- Collier, Paul, 2007. The Bottom Billion. Oxford University Press, Oxford.

- Cumhuriyet, April 9, 2010. Bilim Teknoloji. Turkiye'de Gelir ve Yasam Kosullari Arastirmalari. pp. 10-11.

- Derber, C., 1998. Corporation State. St. Martin's Press, New York.

- Jackson, Tim, 2009. Prosperity without Growth: Economics for a Finite Planet. Earthscan, London.

- Estes, R., 1996. Tyranny of the Bottom Line. Berrett-Koehler Publisher, San Francisco.

- Feenberg, Daniel R. and James M. Poterba, December, 1992. "Income Inequality and the Income of Very High Income Taxes". NBER Working Paper No: 4229.

- Friedman, M., 1970. The Social Responsibility of Business is to Increase its Profits. In T.L. Beauchamp and N. Bowie (Eds.), in Ethical Theory and Business. Prentice Hall, Englewood Cliffs NJ.

- Galbraith, K. J., 1998. Created Unequal: The Crisis of American Pay. The Free Press, New York.

- Garten, Jeffrey E.,1997. The Big Ten: The Big Emerging Markets and How They Will Change Our Lives. Basic Books, New York.

- Haussmann, Ricardo, 1998. Inter-American Development Bank. The John Hopkins University Press, New York.

- Isaak, Robert A., 2005. The Globalization Gap. Prentice Hall, New York.

- Kloby, Jerry, 1990. Inequality, Power and Development. Humanity Books, New York.

- Knox, Paul and John Agnew, 1998. The Geography of the World Economy. John Wiley, New York.

- Marber, Peter, 2009. Seeing the Elephant. John Wiley and Sons, Inc., New York.

- Marber, Peter, 1998. From Third World To World Class. Addison Wesley Longman, Inc., Reading, MA.

- $\quad$ Reich, R.B., 2009. Super Capitalism. Vintage Books, New York.

- Ricardo, David, 1981. Principal of Political Economy, and Taxation. Cambridge University Press, Cambridge.

- $\quad$ Rose, Nancy I., Winter 1994-95. Executive Compensation, NBER Reporter.

- Sachs, Jeffrey D., 2008. Common Wealth: Economics for a Crowded Planet. Oxford University Press, New York.

- Sachs, Jeffrey D., 2005. The End of Poverty. Penguin Group (USA), New York.

- Smith, Adam, 1976. Wealth of Nations. Modern Library, New York.

- Speth G. James, 2008. The Bridge at the Edge of the World. Yale University Press, New Haven.

- Stiglitz E. Joseph and Andrew Charlton, 2005. Fair Trade for All. How Trade Promote Development. Oxford University Press, New York.

- Şen, Asım, 2009. Leadership for Twenty-First Century: Lessons from Ataturk's Leadership. Book Surge Publishing, Las Vegas, NV.

- Şen, Asım, 2003. Democratic Management: Total Quality with Liberty and 
Equality. University Press of America, Inc., New York.

- SSen, Asım, 1982. Science, Technology and Development: Lessons from Japan. METU Faculty of Administrative Sciences, Ankara.

- Yunus, Muhammad, 2007. Creating World without Poverty. Public Affairs, New York.

- Thurow, Lester C., 1996. The Future of Capitalism. William Morrow and Company, Inc., New York.

- Wilkinson Richard and Kate Pickett, 2009. The Spirit Level: Why Greater Equality Makes Societies Stronger. Bloomsbury Press, New York. 